\title{
METODE EKSPERIMEN UNTUK MENINGKATKAN HASIL BELAJAR DAN JIWA KEWIRAUSAHAAN SISWA SEKOLAH DASAR
}

\author{
Ninditya Enggawati Hayuningtyas *, Arfilia Wijayanti, Muhajir
}

PGSD, Fakultas Ilmu Pendidikan, Universitas PGRI Semarang

\begin{abstract}
Abstrak:Tujuan dalam penelitian untuk mengetahui keefektifan metode ekperimen terhadap hasil belajar dan jiwa kewirausahaan siswa kelas IV di SDN 1 Kedungtuban Kabupaten Blora. Jenis penelitian ini adalah penelitian kuantitatif dalam bentuk Pre Experimental Design dengan desain penelitian One Group Pretest-Posttest Design. Populasi penelitian adalah seluruh siswa SDN 1 Kedungtuban Kabupaten Blora tahun pelajaran 2016/2017. Data dalam penelitian ini diperoleh melalui tes, angket dan dokumentasi. Pada nilai pretest yang telah dilaksanakan diperoleh nilai rata-rata sebesar 50,154 dan tes akhir posttest dengan nilai rata-rata sebesar 70,154. Berdasarkan hasil yang diperoleh uji normalitas data Lodari nilai pretest sebesar 0,146 dan taraf signifikan $\alpha=5 \%$ diperoleh $\mathrm{L}=0,234$ karena $\mathrm{L}>$ Lo nilai $\mathrm{n}=13$ diperoleh $\mathrm{Lo}=0,141$ dan taraf signifikan $\alpha=5 \%$ diperoleh $\mathrm{L}=0,234$. Jadi $\mathrm{L}>$ Lo maka hipotesis nol diterima.Pada jiwa kewirausahaan dinilai berdasarkan angket. Sehingga didapat hasil yang mendapatkan kategori nilai baik ada 3 anak, yang mendapatkan kategori cukup baik ada 7 anak, dan yang mendapatkan kategori nilai kurang baik ada 3 anak. Dapat disimpulkan bahwa siswa kelas IV SDN 1 Kedungtuban mempunyai jiwa kewirausahaan karena dari persentase yang didapat $77 \%$ dari 13 siswa mempunyai jiwa kewirausahaan. Artinya metode eksperimen efektif terhadap hasil belajar dan jiwa kewirausahaan siswa kelas IV SDN 1 Kedungtuban
\end{abstract}

Kata kunci : Metode Eksperimen, Hasil Belajra, Jiwa Kewirausahaan.

Abstract: The purpose of this research is to know the effectiveness of experimental method on learning outcomes and entrepreneurship spirit of fourth grade students at SDN 1 Kedungtuban Blora. Type this of research is quantitative research in the form. Pretest-Posttest Experiment Design. The study population was all students of SDN 1 Kedungtuban Blora Regency in the academic year 2016/2017. Data in this study. At the pretest value that has been implemented at an average of 50.154 and the average exchange rate. Based on the results obtained by the normality test data Lodari pretest value of 0.146 and significant level $\alpha=5 \%$ obtained $L=0.234$ because $L>$ Lo value $n$ $=13$ due Lo $=0.141$ and significant level $\alpha=5 \%$ obtained $\mathrm{L}=0.234$. So $\mathrm{L}>$ Lo then the null hypothesis accepted. On entrepreneurial spirit based on questionnaire. Results obtained a good category there are 3 children, who have a pretty good category there are 7 children, and the category is not good there are 3 children. It can be concluded that the fourth grade students of SDN 1 Kedungtuban have entrepreneurial spirit because of

Alamat korespondensi: Jalan Sidodadi Timur No. 24, Karangtempel, Semarang e-mail: nindityahayuningtyas@gmail.com 
which divided $77 \%$ of 13 students have entrepreneurial spirit. Effective learning method for learning outcomes and entrepreneurship spirit of fourth grade students of SDN 1 Kedungtuban

Keywords: Experimental Method, Belajra Results, Entrepreneurship Soul.

\section{PENDAHULUAN}

Indonesia merupakan negara maritim tidak hanya memiliki Sumber Daya Manusia tetapi mempunyai banyak pulau dan suku bangsa serta Sumber Daya Alam yang melimpah. Dengan banyaknya Sumber Daya Alam yang ada, maka penduduk di wilayah Indonesia harus bisa memanfaatkan Sumber Daya Alam tersebut dengan baik yaitu dengan cara belajar. Seperti yang tertera pada Peraturan Pemerintah Republik Indonesia Nomor 32 Tahun 2013 tentang Perubahan Atas Peraturan Pemerintah Nomor 19 Tahun 2005 tentang Standar Nasional Pendidikan yang berisi "Bahan kajian ilmu pengetahuan alam, antara lain, fisika, biologi, dan kimia dimaksudkan untuk mengembangkan pengetahuan, pemahaman, dan kemampuan analisis Siswa terhadap lingkungan alam dan sekitarnya".

Seperti yang diungkapkan Hamdani (2011: 20), bahwa belajar adalah suatu proses usaha yang dilakukan seseorang untuk memperoleh perubahan tingkah laku yang baru secara keseluruhan, sebagai hasil pengalamannya sendiri dalam interaksi dengan lingkungannya. Jadi belajar merupakan suatu proses dimana seseorang akan menambah pengalamannya dan akan merubah tingkah laku. Belajar tidak hanya berupa lingkungan sosial tetapi juga berupa lingkungan alam.

Ilmu Pengetahuan Alam (IPA) atau sains menurut James Conant dalam (Samatowa, 2010: 1) mendefinisikan "suatu deretan konsep serta skema konseptual yang berhubungan satu sama lain, dan yang tumbuh sebagai hasil eksperimentasi dan observasi, serta berguna untuk diamati dan dieksperimentasikan lebih lanjut". Sementara itu, A.N. Whitehead dalam (Samatowa, 2010: 1) menyatakan bahwa sains dibentuk karena pertemuan dua orde pengalaman.Orde pertama didasarkan pada hasil observasi terhadap gejala/fakta (orde observasi), dan kedua didasarkan pada konsep-konsep manusia mengenai alam (orde konsepsional). Winaputra dalam (Samatowa, 2010: 3) 
juga mengemukakan bahwa IPA tidak hanya merupakan kumpulan pengetahuan tentang benda atau makhluk hidup, tetapi memerlukan kerja, cara berpikir, dan cara memecahkan masalah.

Berdasarkan pendapat ketiga ahli di atas dapat disimpulkan bahwa IPA atau sains adalah suatu ilmu yang tidak hanya mempelajari tentang benda dan makhluk hidup yang ada di muka bumi saja, tetapi semua yang ada di alam semesta juga dipelajarinya.Jadi IPA atau sains tidak hanya kumpulan pengetahuan saja tetapi sebagai hasil pengamatan dan eksperimen yang berdasarkan hasil observasi yang melibatkan pancaindra.

Pembelajaran IPA dengan segala kajiannya mempunyai manfaat untuk melatih berfikir kritis dan objektif serta terampil pada siswa terutama pada siswa sekolah dasar. Seperti yang diungkapkan ahli tentang keterampilan proses sains.

Beberapa keterampilan proses sains yaitu (1) mengamati, (2) mencoba memahami apa yang di amati, (3) mempergunakan pengetahuan baru untuk meramalkan apa yang terjadi, (4) menguji ramalan-ramalan dibawah kondisikondisi untuk melihat apakah ramalan tersebut benar. Selanjutnya Paolo dan
Marten juga menegaskan bahwa dalam IPA tercakup juga coba-coba dan melakukan kesalahan, gagal dan mencoba lagi (Samatowa, 2010: 5).

Jadi, dalam pembelajaran IPA siswa tidak hanya mendapatkan pengetahuan saja, tetapi dengan mencoba-coba dia akan mendapatkan pengetahuan baru dan pengalaman langsung. Setelah belajar terdapat perubahan tingkah laku pada diri siswa baik pengetahuan, sikap maupun pengetahuaanya.

Pembelajaran IPA yang terjadi di SDN 1 Kedungtuban Kabupaten Blora kelas IV belum sesuai dengan karakteristik pembelajaran IPA pada umumnya. Pada saat peneliti mengobservasi cara pengajaran yang dilakukan oleh guru kelas IV yaitu Bapak Yuana A. Ma. Pd, beliau masih menggunakaan metode ceramah dan penugasan. Belum memanfaatkan lingkungan sekitar sebagai proses pembelajaran baik itu berupa alat peraga atau memanfaatkan apa yang ada di lingkungan sekitar dan belum menggunakan metode eksperimen serta observasi. Permasalahan ternyata tidak itu saja, hasil belajar siswa masih rendah dalam pembelajaran IPA, hal ini dibuktikan dengan nilai yang masih di bawah Kriteria Ketuntasan 
Minimal (KKM) yaitu 61 hal ini disebabkan karena siswa kurang mampu memahami materi pembelajaran.

Berdasarkan hasil pengamatan dari hasil evaluasi mata pelajaran IPA tentang perubahan wujud benda kelas IV SDN 1 Kedungtuban Kabupaten Blora tahun pelajaran 2016/2017. Dari jumlah siswa 13 , nilai siswa yang tuntas hanya 4 siswa atau 35,71\% dengan nilai rata-rata 67,75 dan yang belum tuntas ada 9 siswa atau $64,29 \%$ dengan nilai rata-rata 54,22.

Hamdani (2011: 80) mengatakan bahwa metode pembelajaran adalah cara yang digunakan guru untuk menyampaikan pelajaran kepada siswa. Macammacam metode pembelajaran menurut Hamdani (2011: 156) antara lain :(1) metode ceramah, (2) metode demonstrasi dan eksperimen, (3) metode tanya jawab, (4) metode penampilan, (5).

Metode eksperimen adalah metode pemberian kesempatan kepada anak didik perorangan atau kelompok untuk dilatih melakukan suatu proses atau percobaan.

Menurut Djamarah dalam (Hamdayama, 2015: 125) metode eksperimen adalah cara penyajikan pelajaran, dimana siswa melakukan percobaan dengan mengalami sendiri sesuatu yang dipelajari. Dalam proses belajar mengajar dengan metode eksperimen, siswa diberi kesempatan untuk mengalami sendiri atau melakukan sendiri, mengikuti suatu proses, mengamati suatu objek, keadaan atau proses sesuatu.

Dengan demikian, siswa dituntut untuk mengalami sendiri, mencari kebenaran, atau mencoba mencari suatu hukum atau dalil, dan menarik kesimpulan dari proses yang dialaminya.

Penggunaan metode eksperimen mempunyai tujuan agar siswa mampu mencari dan menemukan sendiri berbagai jawaban atau persoalan-persoalan yang dihadapinya dengan mengadakan percobaan sendiri. Dengan metode eksperimen siswa terlatih untuk berfikir secara ilmiah.Melalui metode eksperimen siswa juga dapat menemukan bukti kebenaran dari teori yang telah dipelajarinya.

Menurut Samatowa dalam (Asmawir, 2014:184) IPA diajarkan melalui percobaan-percobaan yang dilakukan sendiri oleh anak, maka IPA tidaklah merupakan mata pelajaran yang bersifat hafalan belak. Sejalan dengan itu pula, mengemukakan bahwa ilmu-ilmu pengetahuan alam telah lama mengembangkan metode eksperimen dengan hasil yang 
memuaskan. Sehingga masalah-masalah seperti: menggunakan metode ceramah dalam pembelajaran, kurang melibatkan siswa dalam pembelajaran sehingga siswa kurangaktif, contoh hanya diilustrasikan di papan tulis. Serta pembelajaran yang tidak sesuai dengan karakteristik IPA tidak akan terulang lagi dalam pembelajaran.

Menurut asmawir (2014: 196) yang telah menggunakan penelitian yang bersangutan dengan metode eksperimen ia mengatakan bahwa dalam sebuah penelitian yang menggunakan metode eksperimen oleh Nikmah (2012) menyatakan bahwa penggunaan metode eksperimen pada mata pelajaran IPA dapat meningkatkan prestasi belajar siswa, Dengan ketuntasan klasikal yang hanya mencapai $72,73 \%$ pada Siklus II dan Meningkat mencapai $100 \%$ pada siklus 2. Begitupun menurut Aditya Masyitha (2010) bahwa metode eksperimen yang dilakukan dalam penelitian ini adalah salah satu alternatif yang sangat tepat didalam meningkatkan hasil belajar siswa yang mula-mula siswa hanya mencapai nilai ketuntasan klasikal $73 \%$ setelah tes akhir diperoleh nilai ketuntasan klasikal sebesar 82,3\%.
Jadi dapat disimpulkan bahwa metode eksperimen dapat meningkatkan hasil pembelajaran IPA, karena metode eksperimen diajarkan melalui percobaan-percobaan yang dilakukan sendiri oleh anak dan tidak berupa hafalan belaka.

Pembelajaran IPA tidak berkaitan dengan ilmu pengetahuan alam yang hanya mempelajari tentang alam, tetapi pembelajaran IPA juga merupakan pembelajaran terpadu.Pembelajaran terpadu merupakan pembelajaran yang dapat berkaitan dengan beberapa mata pelajaran untuk memberikan pengalaman belajar yang bermakna bagi peserta didik.Pembelajaran IPA dapat dikaitkan dengan Pembelajaran Kewirausahaan.

Kewirausahaan menurut Suryana dalam (Rachmawati, 2009: 7) adalah kemampuan kreatif dan inovatif yang dijadikan dasar, kiat dan sumber daya untuk mencari peluang menuju sukses.Kewirausahaan dapat membuat seseorang berfikir kreatif dan inovatif. Karena mereka bersaing di dunia ekonomi yang sangat luas, jika tidak berusaha kreatif dan inovasi akan kalah dengan usaha yang lain. Kepribadian yang kreatif dan inovatif tersebut di- 
tunjukkan dengan berbagai macam perilaku, seperti mudah bergaul, suka bekerja keras, percaya diri, berani mengambil resiko, mandiri, mampu mengendalikan diri sendiri, dan mau berinovasi atau mencoba hal-hal baru.

Kewirausahaan sangat penting diajarkan sejak dini menurut Gorman dan Hanlon dalam (Dewanto, 2013: 136) kewirausahaan dapat dipengaruhi secara positif oleh program pendidikan.Menurut Jones dan England dalam (Dewanto, 2013: 136) bahwa pendidikan

\section{METODE PENELITIAN}

Jenis penelitian ini adalah penelitian kuantitatif dalam bentuk Pre Experimental Design dengan desain penelitian One Group Pretest-Posttest Desaign. Penelitian ini dilaksanakan di kelas IV SDN 1 Kedungtuban Kabupaten Blora tepatnya di Jl. Bendungan Mursapa Desa Kedungtuban Kecamatan Kedungtuban Kabupaten Blora. SDN 1 Kedungtuban berada di bawah naungan UPTD TK/SD Kecamatan Kedungtuban Kabupaten Blora. Penelitian ini akan dilaksanakan pada bulan Oktober 2016 sampai dengan Januari 2017. kewirausahaan secara luas dapat dilihat dari segi keterampilan yang dapat diajarkan dan karakteristik yang memungkinkan seseorang menciptakan dan mengembangkan rencana baru dan inovatif.

Menurut pemikiran para ahli dapat disimpulkan bahwa pendidikan kewirausahaan diajarkan sejak dini sangat baik, karena selain dapat menumbuhkan keterampilan yang inovatif pada diri anak, mereka juga mendapatkan pengalaman yang nyata.

Populasi dalam penelitian ini adalah seluruh siswa kelas IV SDN 1 Kedungtuban Kabupaten Blora sebanyak 13 siswa. Sampel yang diambil adalah 13 kelas IV dengan menggunakan teknik non probability sampling atau sampling jenuh. Sampling jenuh adalah teknik pengambilan sampel dimana semua anggota populasi digunakan sebagai sampel.

Metode pengumpulan data meliputi (1) Tes Menurut Arikunto (2010: 193) "tes adalah serentetan pertanyaan atau alat lain yang digunakan untuk mengukur keterampilan, pengetahuan inteligensi, kemampuan atau bakat yang dimiliki oleh individu atau kelompok.(2)Observasi sebagai teknik 
pengumpulan data mempunyai ciri yang spesifik bila dibandingkan dengan teknik lain. Menurut Hadi (dalam Sugiyono, 2012: 203) "observasi merupakan suatu proses yang kompleks, suatu proses yang tersusun dari berbagai proses biologis dan psikologis“. Jadi dalam penelitian ini menggunakan lembar observasi yang digunakan sebagai acuan dalam melakukan observasi.(3) Dokumentasi Menurut Arikunto (2010: 202) "Metode dokumentasi dapat merupakan metode utama apabila peneliti melakukan pendekatan analisis isi (content analysis). Didalam melaksanakan metode dokumen, peneliti menyelidiki benda-benda tertulis seperti buku-buku, majalah, dokumen, peraturan-peraturan, notulen rapat, catatan harian, dan sebagainya".

\section{PEMBAHASAN}

Kegiatan pembelajaran dilakukan sebanyak 3 kali masing-masing dengan materi dan eksperime yang berbeda pada setiap pertemuan. Pada saat pembelajaran menggunakan metode eksperimen siswa lebih antusias mengikuti pembelajaran. Kerjasama antar siswa juga semakin meningkat, hal ini nampak pada saat siswa melakukan eksperimen dalam kelompoknya.
Selain mengamati proses berlangsungnya kegiatan belajar mengajar, peneliti juga mengolah hasil evaluasi untuk mengetahui sejauh mana kemajuan hasil belajar siswa baik sebelum diberi perlakuan (pretest) maupun sesudah diberi perlakuan (posttest). Data yang diperoleh dapat dilihat pada Tabel 1 :

Tabel 1 Distribusi Nilai Pretest dan Posttest

\begin{tabular}{ccc} 
Keterangan & Pretest & Posttest \\
\hline Nilai terendah & 32 & 48 \\
Nilai tertinggi & 68 & 96 \\
Rata-rata & 50,154 & 70,154 \\
Siswa tuntas & 1 & 10
\end{tabular}

Berdasarkan tabel di atas, rata-rata pretest siswa SDN 1 Kedungtuban dalam materi perubahan wujud benda adalah 50,154 dengan nilai tertinggi 68 dan nilai terendah 32. Siswa yang mendapat nilai di atas KKM atau di atas 61 yaitu satu siswa dan yang tidak tuntas ada 12 siswa. Setelah dikenai perlakuan yaitu dengan menggunakan metode eksperimen ratarata nilai menjadi 70,154 dengan nilai tertinggi 96 dan nilai terendah 48 yang artinya 10 siswa tuntas dan tiga siswa belum tuntas. Berdasarkan perbandingan analisis data pretest dan posttest dapat 
disimpulkan bahwa perolehan data posttest lebih baik dibandingkan pretest.

Dari Tabel 1 dapat diperoleh diagram istogram pada Gambar 1, sebagai berikut:

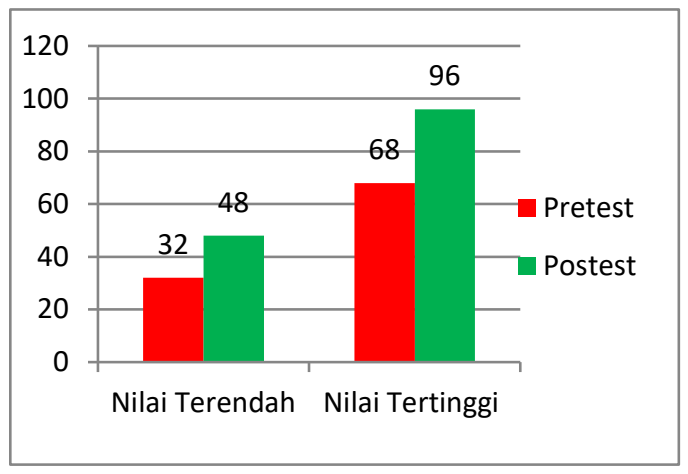

Gambar 1 Diagram Perbandingan Nilai Pretest dan Postest

Dari Gambar 5.1, dapat dilihat perbandingan antara nilai pretest yang dilakukan sebelum pembelajaran dengan nilai posttest yang diperoleh pada akhir pembelajaran mengalami kenaikan. Seperti yang terlihat pada tabel di atas, nilai posttest tertinggi yaitu 96, terendah 48 dengan rata-rata 70,154 dan 10 siswa memenuhi KKM menunjukkan bahwa ada kenaikan dari hasil pretest. Perbedaan itu diakibatkan dari penggunaan metode eksperimen, sehingga nilai mengalami peningkatan yang signifikan.

Pengambilan hasil belajar afektif pada pelajaran IPA diambil dari hasil pengamatan yang dilakukan pada saat pertemuaan pertama sampai pertemuan ketiga. Pada aspek afektif ini yang dinilai dari siswa yaitu tanggung jawab, rasa ingin tahu, dan disiplin.

Dari skor yang siswa dapat setiap pertemuan dihitung menggunakan nilai akhir. Nilai akhir siswa dapat dihitung dengan rumus : Nilai Akhir = $\frac{\text { Skor Perolehan }}{\text { Skor Maksimal }}$ x 100. Lihatlah nilai akhir pada setiap pertemuan pada Tabel 2 :

Tabel 2 Distribusi Nilai Afektif

\begin{tabular}{cccc}
\hline Ket & $\begin{array}{c}\text { Perte- } \\
\text { muan 1 }\end{array}$ & $\begin{array}{c}\text { Perte- } \\
\text { muan 2 }\end{array}$ & $\begin{array}{c}\text { Perte- } \\
\text { muan 3 }\end{array}$ \\
\hline $\begin{array}{c}\text { Nilai teren- } \\
\text { dah }\end{array}$ & 25 & 58,3 & 41,6 \\
Nilai & 100 & 91,6 & 100 \\
tertinggi & & & \\
Rata-rata & 76,89 & 83,29 & 79,45 \\
Siswa tuntas & 12 & 12 & 12 \\
\hline
\end{tabular}

Dapat dilihat dari Tabel 2 bahwa rata-rata nilai siswa pada pertemuan pertama yaitu 76,89, pertemuan kedua yaitu 83,29 dan pertemuan ketiga yaitu 79,45. Nilai tertinggi siswa pada pertemuan pertama adalah 100 , pertemuan kedua adalah 91,6 dan pertemuan ketiga 100 . Sedangkan nilai terendah siswa pertemuan pertama adalah 25 , pertemuan kedua adalah 58,3, dan pertemuan ketiga adalah 41,6. Dari Gambar 2 menunjukkan rata-rata siswa pada setiap pertemuan:

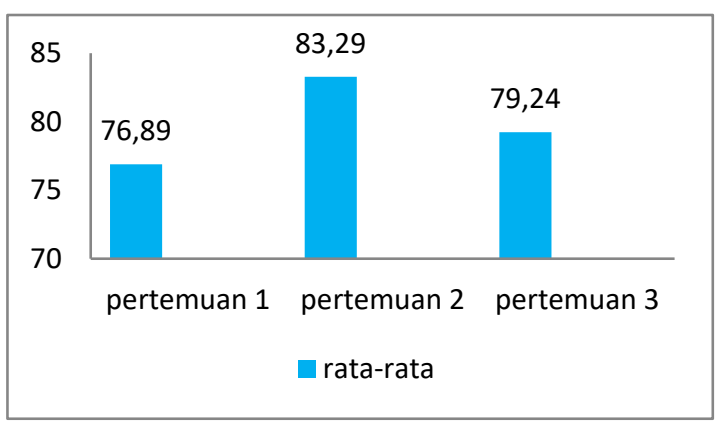

Gambar 2 Diagram Perbandingan Nilai Afektif Setiap Pertemuan

Pengambilan hasil belajar psikomotor pada belajar IPA diambil dari hasil 
pengamatan yang diambil pada saat pembelajaran dan percobaan pada pembelajaran pertama sampai pembelajaran ketiga. Lebih jelasnya dapat dilihat dalam daftar nilai pada Tabel 3 :

\begin{tabular}{cccc}
\multicolumn{4}{c}{ Tabel 3.Distribusi Nilai Psikomotor } \\
Ket & $\begin{array}{c}\text { Perte- } \\
\text { muan 1 }\end{array}$ & $\begin{array}{c}\text { Perte- } \\
\text { muan 2 }\end{array}$ & $\begin{array}{c}\text { Perte- } \\
\text { muan } \\
3\end{array}$ \\
\hline $\begin{array}{c}\text { Nilai } \\
\text { terendah } \\
\text { Nilai }\end{array}$ & 50 & 75 & 75 \\
tertinggi & 100 & 100 & 100 \\
$\begin{array}{c}\text { Rata-rata } \\
\text { Siswa }\end{array}$ & 80,76 & 98,08 & 96,15 \\
tuntas & 12 & 0 & 0
\end{tabular}

Dapat dilihat dari Tabel 3 bahwa rata-rata nilai siswa pada pertemuan pertama adalah 78,82, pertemuan kedua adalah 90,32 dan pertemuan ketiga adalah 89,05. Nilai tertinggi yang didapat siswa pada pertemuan pertama adalah 91,5, pertemuan kedua adalah 91,6 dan pertemuan ketiga adalah 91,6. Dan nilai siswa terendah pada pertemuan pertama adalah 58,3, pertemuan kedua adalah 75 , dan pertemuan ketiga adalah 75 . Sehingga siswa yang belum tuntas ada 1 anak, dan yang 12 anak sudah memenuhi KKM. Dari Gambar 5.3 dapat diketahui rata-rata siswa setiap pertemuan:

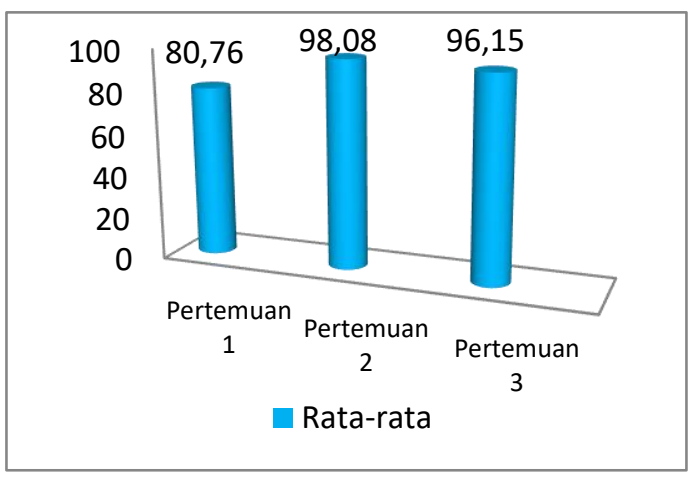

Gambar 3 Diagram Perbandingan Nilai

Psikomotor Setiap Pertemuan

Angket jiwa kewirausahaan digunakan untuk mengetahui seberapa besar jiwa wirausaha yang muncul pada diri siswa. Siswa diminta untuk menjual hasil percobaan tentang pembuatan es puter yang mereka buat secara kelompok. Lalu, hasil yang mereka dapatkan dibagi rata setiap kelompoknya.

Pada tahap ini siswa akan di beri angket untuk mengetahui seberapa besar jiwa kewirausahaan yang tumbuh pada diri siswa. Kriteria atau indikator yang akan di nilai antara lain : (a) Pengambilan resiko, (b) Kepemimpinan, (c) Keorisinilan. Pada angket jiwa kewirausahaan terdiri dari 10 pernyataan yang akan di jawab oleh masing-masing siswa. Pada setiap pernyataan terdiri dari tiga pilihan yaitu pilihan jawaban tidak setuju, setuju, dan sangat setuju.Dari angket yang dikerjakan oleh siswa, maka dalam menentukan nilai akhir menggunakan rumus

$$
\begin{aligned}
& \text { Nilai }=\frac{\text { Skor Perolehan }}{\text { Skor Maksimal }} \times 100 \\
& \text { Berdasarkan angket jiwa }
\end{aligned}
$$

kewirausahaan kelas IV SDN 1 Kedungtuban didapat hasil bahwa yang 
mendapatkan kategori nilai baik ada 3 anak, yang mendapatkan kategori cukup baik ada 7 anak, dan yang mendapatkan kategori nilai kurang baik ada 3 anak. Sehingga dapat disimpulkan bahwa siswa kelas IV SDN 1 Kedungtuban mempunyai jiwa kewirausahaan karena dari persentase yang didapat $77 \%$ dari 13 siswa mempunyai jiwa kewirausahaan.

Sebelum dilakukan pengujian hipotesis, maka terlebih dahulu dilakukan uji normalitas. Untuk menguji kenormalan distribusi sampel digunakan uji Lilifors. Uji normalitas awal dilakukan pada hasil pretest. Hipotesisnya sebagai berikut:

$\mathrm{H}_{0}=$ Sampel berasal dari populasi berdistribusi normal

$\mathrm{H}_{1}=$ Sampel berasal dari populasi tidak berdistribusi normal

Dari hasil perhitungan tersebut diperoleh data seperti yang tercantum dalam Tabel 4.

Tabel 4. Uji Normalitas Awal

\begin{tabular}{ll}
\hline Keterangan & Nilai \\
\hline $\mathrm{L}_{\text {hitung }}$ & 0,146 \\
$\mathrm{~L}_{\text {table }}$ & 0,234 \\
Kesimpulan & $\mathrm{H}_{0}$ Diterima \\
\hline
\end{tabular}

Dari Tabel 4, dapat dilihat bahwa dengan $n=13$ dan taraf $\alpha=5 \%$, memiliki L hitung $<\mathrm{L}_{\text {tabel }}$ yaitu $0,146<0,234$ maka $\mathrm{H}_{0}$ diterima, sehingga disimpulkan bahwa data nilai pretest siswa berasal dari populasi yang berdistribusi normal.

Untuk menguji kenormalan distribusi sampel, peneliti menggunakan uji Lilifors. Uji normalitas akhir dilakukan pada hasil posttest setelah menggunakan metode eksperimen.

ipotesisnya sebagai berikut:

$\mathrm{H}_{0}=$ Sampel berasal dari populasi berdistribusi normal

$\mathrm{H}_{1}=$ Sampel berasal dari populasi tidak berdistribusi normal

Dari hasil perhitungan tersebut diperoleh data seperti yang tercantum dalam Tabel 5 .

Tabel 5. Uji Normalitas Akhir

\begin{tabular}{cc}
\hline Keterangan & Nilai \\
\hline $\mathrm{L}_{\text {hitung }}$ & 0,141 \\
$\mathrm{~L}_{\text {table }}$ & 0,234
\end{tabular}

Kesimpulan $\quad \mathrm{H}_{0}$ Diterima

Dari Tabel 4.5, dapat dilihat bahwa dengan $n=13$ dan taraf $\alpha=5 \%$, memiliki

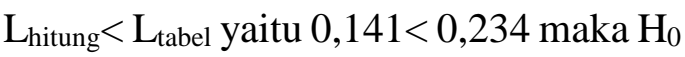
diterima, sehingga disimpulkan bahwa data nilai posttest siswa berasal dari populasi yang berdistribusi normal. Uji hipotesis pada penelitian ini peneliti menggunakan uji-t pihak kanan dengan data nilai hasil belajar pretest dan posttest siswa kelas eksperimen. Hipotesis statistik untuk keperluan $t$-test adalah sebagai berikut:

$\mathrm{H}_{0}$ : Penggunaan metode eksperimen tidak efektif terhadap hasil belajar dan jiwa kewirausahaan siswa kelas IV SDN 1 Kedungtuban Kabupaten Blora materi perubahan wujud benda.

$\mathrm{H}_{\mathrm{a}}$ : Pengunaan metode eksperimen efektif terhadap hasil belajar dan jiwa kewirausahaan siswa kelas IV SDN 1 Kedungtuban Kabupaten Blora materi perubahan wujud benda. 
Berdasarkan hipotesis di atas maka dijumpai kriteria sebagai berikut:

Apabila $t_{\text {hitung }}>t_{\text {tabel }}$ maka $\mathrm{H}_{0}$ ditolak dan $\mathrm{H}_{\mathrm{a}}$ diterima. Artinya ada pengaruh metode eksperimenterhadap hasil belajar siswa mata pelajaran IPA kelas IV SDN 1 Kedungtuban Kabupaten Blora.

Setelah dilakukan analisis data nilai hasil belajar diperoleh rata-rata untuk pretest sebesar 50,154dan postest sebesar 70,154 diperoleh $t_{\text {hitung }}=11,402$ dengan tabel distribusi uji $\mathrm{t}$ diperoleh $\mathrm{n}=$ 13 maka $\mathrm{db}=13-1=12$, dengan taraf signifikansi $5 \%$ didapat nilai $t_{\text {tabel }}=$ 2,179. Karena $t_{\text {hitung }}(11,402)$ $>t_{\text {tabel }}(2,179)$.

Tabel 6. Uji Hipotesis

\begin{tabular}{ll}
\hline \multicolumn{1}{c}{ Keterangan } & \multicolumn{1}{c}{ Nilai } \\
\hline Rata-rata Pretest & 50,154 \\
Rata-rata Postest & 70,154 \\
$\mathrm{~N}$ & 13 \\
$\mathrm{t}$ table & 2,179 \\
$\mathrm{t}$ hitung & 11,402 \\
\hline
\end{tabular}

Jadi nilai $t_{\text {hitung }}>t_{\text {tabel, }}$, Sehingga $\mathrm{H}_{0}$ ditolak dan $\mathrm{H}_{\mathrm{a}}$ diterima, artinya Ada pengaruh metode eksperimen terhadap hasil belajar siswa mata pelajaran IPA kelas IV SDN 1 Kedungtuban.

Pada tahap ini menggunakan kriteria ketuntasan yaitu aspek kognitif, afektif, dan psikomotorik. Metode eksperimen dikatakan dapat mencapai ketuntasan belajar siswa pada materi perubahan wujud benda kelas IV SDN 1 Kedungtuban Kabupaten Blora apabila nilai rata-rata hasil belajar siswa sekurang-kurangnya mencapai $75 \%$ dari jumlah yang mendapat nilai di atas KKM (61). Dari rumus KBL (Ketuntasan Belajar Klasikal) ketuntaaan siswa telah melampaui batas rata-rata yaitu $76,92 \%$ dari $75 \%$.

Pada tahap awal sebelum diberi perlakuan, terlebih dahulu dilakukan uji normalitas awal dengan menggunakan nilai pretest. Hal tersebut dilakukan untuk mengetahui sampel berdistribusi normal atau tidak. Berdasarkan perhitungan yang dilakukan diperoleh kesimpulan bahwa kelas IV SDN 1 Kedungtuban berdistribusi normal karena nilai $\mathrm{L}_{\text {hitung }}<$ $\mathrm{L}_{\text {tabel, }}$, nilai $\mathrm{L}_{\text {tabel }}=0,234$ dengan $\alpha=5 \%$,

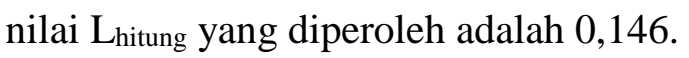

Berdasarkan hasil pretest siswa, maka diperoleh histogram berikut:

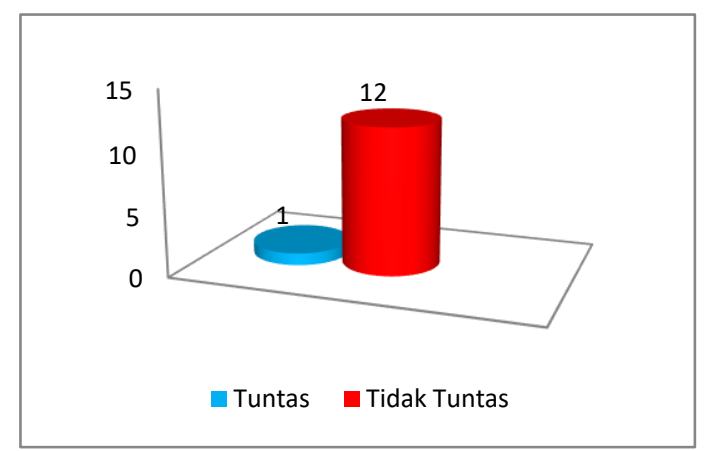

Gambar 4 Diagram Hasil Pretest Siswa

Dari diagram hasil pretest diketahui bahwa 12 siswa tidak memenuhi KKM yang sudah ditetapkan dan 1 siswa memenuhi KKM yang sudah ditetapkan.

Pada tahap akhir dilakukan kembali uji normalitas dengan menggunakan posttest. Berdasarkan perhitungan diperoleh $L_{\text {hitung }}=0,141$ dengan $n=13$ dan taraf nyata $\alpha=5 \%$ didapat $\mathrm{L}_{\text {tabel }}=0,234$ karena $\mathrm{L}_{\text {hitung }}<\mathrm{L}_{\text {tabel }}$ maka disimpulkan 
bahwa kelas tersebut berdistribusi normal.

Berdasarkan hasil postest siswa, maka diperoleh histogram berikut:

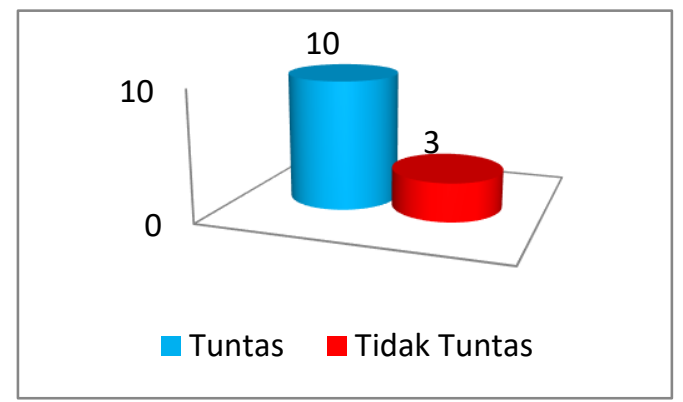

Gambar 5 Diagram Hasil Nilai Postest

Siswa

Nilai posttestmengalami peningkatan. Siswa yang kurang aktif, cenderung bosan dan tidak bersemangat selama pembelajaran menjadi aktif dan bersemangat saat pembelajaran berlangsung menggunakan metode eksperimen.

Data hasil belajar siswa menunjukkan rata-rata nilai postest lebih besar dibanding nilai pretest siswa. Rata-rata nilai pretest adalah 50,15, sedangkan rata-rata nilai postest adalah 70,15. Ketuntasan Belajar Klasikal (KBK) siswa yaitu $76,92 \%$ dari $75 \%$ sehingga dapat dikatakan bahwa hasil belajar siswa melebihi kriteria. Pada Uji hipotesis pada penelitian ini peneliti menggunakan uji-t pihak kanan dengan data nilai hasil belajar pretest dan posttest siswa maka diperoleh hasil pembelajaran menggunakan metode eksperimen menghasilkan nilai rata-rata 70,15 dengan KKM 61, thitung $=11,402$ dengan $\mathrm{n}=13$ dan $\mathrm{t}_{\text {tabel }}=2,179$. Berdasarkan hasil perhitungan tersebut diketahui bahwa $t_{\text {hitung }}>t_{\text {tabel}}$, sehingga dapat disimpulkan bahwa metode eksperimen efektifterhadap hasil belajar siswa mata pelajaran IPA kelas IV SDN 1 Kedungtuban Kabupaten Blora.

Pada aspek afektifrata-rata siswa pada pertemuan pertama yaitu 76,89 , pertemuan kedua yaitu 83,29 dan pertemuan ketiga yaitu 41,6. Nilai tertinggi siswa pada pertemuan pertama adalah 100, pertemuan kedua adalah 91,6 dan pertemuan ketiga 100. Sedangkan nilai terendah siswa pertemuan pertama adalah 25, pertemuan kedua adalah 58,3, dan pertemuan ketiga adalah 41,676.

Pada aspek psikomotor rata-rata nilai siswa pada pertemuan pertama adalah 80,76, pertemuan kedua adalah 98,08, dan pertemuan ketiga adalah 96,15 . Nilai tertinggi yang didapat siswa pada pertemuan pertama, kedua dan ketiga adalah 100. Dan nilai siswa terendah pada pertemuan pertama adalah 50 , pertemuan kedua adalah 75 , dan pertemuan ketiga adalah 75 . Sehingga siswa yang belum tuntas ada 1 anak, dan yang 12 anak sudah memenuhi.

Siswa melakukan eksperimen dengan percobaan pembuatan es puter. Pada pembuatan es puter semua kelompok behasil membuat hasil karya es puternya dengan baik dan berhasil. Setelah pembuatan es puter selesai siswa menjual hasil karyanya di lingkungan sekolah. Dengan antusias siswa menawarkan es puter tersebut mula-mula dari ruang guru. Dan banyak guru yang berminat membelinya, setelah keruang guru mereka menjual es puternya di kelas-kelas dan lingkungan sekolahan. Setelah 
semuanya laku, hasil es puter tersebut dibagikan sama rata setiap kelompok dengan bantuan peneliti.

Pada penelitian sebelumnya yang di lakukan oleh Asmawir (2014:196) bahwa :

Dalam sebuah penelitian yang menggunkan metode eksperimen oleh Nikmah (2012) menyatakan bahwa penggunaan metode eksperimen pada mata pelajaran IPA dapat meningkatkan prestasi belajar siswa, Dengan ketuntasan klasikal yang hanya mencapai 72,73\% pada Siklus II dan Meningkat mencapai $100 \%$ pada siklus 2. Begitupun menurut Aditya Masyitha (2010) bahwa metode eksperimen yang dilakukan dalam penelitian ini adalah salah satu alternatif yang sangat tepat didalam meningkatkan hasil belajar siswa yang mulamula siswa hanya mencapai nilai ketuntasan klasikal $73 \%$ setelah tes akhir diperoleh nilai ketuntasan klasikal sebesar $82,3 \%$.

Pada penelitian yang dilakukan Asmawir membuktikan bahwa metode eksperimen pada pembelajaran IPA dapat meningkatkan hasil belajar siswa. Sehingga peneliti mengunakan metode eksperimen untuk meneliti dan meningkatkan hasil belajar siswa.

Pada jiwa kewirausahaan dinilai berdasarkan angket yang diberikan kepada siswa yang terdiri dari jawaban Sangat Setuju, Setuju, dan Tidak Setuju beserta alasannya. Sehingga Berdasarkan angket jiwa kewirausahaan kelas IV SDN 1 Kedungtuban didapat hasil bahwa yang mendapatkan kategori nilai baik ada 3 anak, yang mendapatkan kategori cukup baik ada 7 anak, dan yang mendapatkan kategori nilai kurang baik ada 3 anak. Sehingga dapat disimpulkan bahwa siswa kelas IV SDN 1 Kedungtuban mempunyai jiwa kewirausahaan karena dari persentase yang didapat $77 \%$ dari 13 siswa mempunyai jiwa kewirausahaan.

Dari beberapa aspek kognitif, aspek afektif dan aspek psikomotor ratarata hanya ada satu siswa yang tidak tuntas dalam pembelajaran. Hal ini disebabkan, siswa tersebut mempunyai keterbelakangan mental. Pada waktu pembelajaran dimulai siswa tersebut hanya tidur didalam kelas, lalu berjalanjalan sesuka hatinya, tidak pernah mau mendengarkan guru berbicara.

Pada awal peneliti melakukan penelitian, guru kelas serta guru-guru yang lain sebelumnya menceritakan kekurangan anak tersebut. Dan tidak ada guru yang memarahinya karena guruguru sudah mengetahui kelemahan anak tersebut.

Dapat disimpulkan bahwa hipotesis yang peneliti laksanakan terbukti kebenarannya, yaitu hasil belajar siswa setelah menggunakan metode eksperimen lebih baik yang artinya terdapat "Keefektifan Metode Eksperimen Terhadap Hasil Belajar Siswa dan Jiwa Kewirausahaan Siswa Kelas IV SDN 1 Kedungtuban Kabupaten Blora”.

\section{KESIMPULAN}

Berdasarkan analisis data, hasil penelitian dan pembahasan pada penelitian ini dapat disimpulkan bahwa 
metode eksperimen efektif terhadap hasil belajar dan jiwa kewirausahaan pada materi pembelajaran perubahan wujud benda kelas IV SDN 1 Kedungtuban. Hasil belajar pada penelitian ini mengalami peningkatan. Rata-rata hasil belajar posttest lebih tinggi dari hasil belajar pretest. Hal ini dibuktikan hasil uji $\mathrm{t}$ yaitu $\mathrm{t}_{\text {hitung }}>\mathrm{t}_{\text {tabel }}$ yaitu 11,401 > 2,179. Adapun aspek afektif rata-rata nilai siswa yang diperoleh siswa pada pertemuan pertama yaitu 76,89 , pertemuan kedua yaitu 83,29 dan pertemuan ketiga yaitu 79,45. Nilai psikomotor siswa memperoleh rata-rata nilai pada pertemuan pertama adalah 80,76 , pertemuan kedua adalah 98,08, dan pertemuan ketiga adalah 96,15. Dan jiwa kewirausahaan siswa memperoleh ratarata $77 \%$ dari 13 siswa, sehingga dapat disimpulkan bahwa "Metode Eksperimen Efektif terhadap Hasil Belajar dan Jiwa Kewirausahaan Siswa Kelas IV SDN 1 Kedungtuban”.

\section{DAFTAR PUSTAKA}

Ariani, Dorothea Wahyu. 2016. Pengantar Bisnis. Tangerang Selatan: Universitas Terbuka.

Arikunto, Suharsimi. 2010. Prosedur Penelitian: Suatu Pendekatan Praktik. Jakarta: PT. Rineka Cipta.

Aksara.

. 2013.Dasar-Dasar Evaluasi Pendidikan(Edisi 2). Jakarta: Bumi

Asmawir. 2014. Upaya Meningkatkan Hasil Belajar Siswa Melalui Metode Eksperimen pada Materi Pesawat Sederhana pada Mata Pelajaran IPA Kelas V SDN No. 3 Siboang. Siboang.

Aqib, Zainal. 2009. Belajar dan Pembelajaran di Sekolah Dasar. Bandung: CV. YRAMA WIDYA.

Alma, Buchari. 2002. Kewirausahaan. Bandung: CV. ALFABETA

Departemen Pendidikan Nasional. 2008. Kamus Besar Bahasa Indonesia Pusat Bahasa Edisi Ke Empat. Jakarta: PT Gramedia Pustaka Umum.

Dewanto, Wawan. 2013. Inovasi dan Kewirausahaan Sosial. Bandung: Alfa Beta.

Dimyati dan Mudjiono. 2010. Belajar dan Pembelajaran. Jakarta: PT. Rineka Cipta.

Djamarah, Syaiful Bahri dan Aswan Zain. 2010. Strategi Belajar Mengajar. Jakarta: PT. Rineka Cipta. 
Hamdani. 2011. Strategi Belajar Mengajar. Bandung: CV Pustaka Setia.

Hamdayama, Jumanta. 2014. Model dan Metode Pembelajaran Kreatif dan Berkarakter. Bogor: Ghalia Indonesia.

Kunandar. 2013. Penilaian Hasil Belajar Peserta Didik Berbasis Kurikulum 2013. Jakarta: Persada.

Kurnia, Albert dan Vina Merliana. 2015. Sukses Berwirausaha dengan Kreatif. Teori: Praktik Berwirausaha Mandiri. Bandung: Alfa Beta.

Pembukaan Undang-Undang Dasar 1945.

Peraturan Menteri Pendidikan Nasional Nomor 22 Tahun 2006 tentang Standar Isi (SI), Nomor 23 Tahun 2006 tentang Standar Kompetensi Lulusan (SKL), dan Nomor 24 Tahun 2006 tentang Pelaksanaan dari kedua Peraturan Mendiknas.

Purwanto. 2014. Evaluasi Hasil Belajar. Yogyakarta: Pustaka Belajar.

Putra, Sitiatava Rizema. 2013. Desain Belajar Mengajar Kreatif Berbasis Sains. Yogyakarta: DIVA Pres.

Retnoningsih dan Suharno. 2009. Kamus Besar Bahasa Indonesia. Semarang: CV. Widya Karya.

Rachmawati, Rina. 2009. Pendidikan Anak Usia Dini Dalam Upaya Menumbuhkan Jiwa Kewirausahaan. rina_nafina@yahoo.co.id. Semarang.

Samatowa, Usman. 2010. Pembelajaran IPA di Sekolah Dasar. Jakarta: PT. Indeks.

Siregar, Eveline dan Hartini Nara. 2014. Teori Belajar dan Pembelajaran. Bogor: Ghalia Indonesia.

Sudjana. 2002. Metoda Statistika. Bandung : PT Tarsito Bandung.

Sugiyono, 2010. Metodologi Penelitian Pendidikan Pendekatan Kuantitatif, Kualitatif, dan $R \& D$. Bandung: Alfabeta.

2012. Metodelogi Penelitian Pendidikan. Bandung: Alfabeta.

2015. Metode Penelitian Kuantitatif, Kualitatif dan R\&D. Bandung: Alfabeta.

Suprijono, Agus. 2009. Cooperative Learning. Yogyakarta: PUSTAKA PELAJAR.

. 2014. Cooperative Learning Teori dan Aplikasi PAIKEM. Yogyakarta: Pustaka Pelajar. 
Uno, Hamzah, B dan Nurdin Mohammad. 2012. Belajar dengan Pendekatan Pembelajaran Aktif Inovatif Lingkungan Kreatif Efektif Menarik. Jakarta: BUMI AKSARA.

UU Nomor 20 Tahun 2003 tentang Sistem Pendidik Nasional dan diterapkan berdasarkan Peraturan Pemerintah Nomor 19 Tahun 2005 tentang Standart Nasional Pendidikan.

Windrawan, Puguh. 2011. Belajar Kaya: Cara Memotivasi Anak Anda Agar Terampil Berwirausaha. Jogjakarta: A+Plus Books. 